\title{
EFFICIENCY OF ESSENTIAL OILS AND NANO-MALATE IN REDUCTION OF ETHYLENE PRODUCTION AND EXTENSION OF VASE LIFE OF CUT EUSTOMA GRANDIFLORUM MARIACHII. CV. BLUE FLOWERS
}

\author{
Vahid Abdossi*, Farshid Esmaeili and MohSEn Kazemi \\ Department of Horticulture, Science and Research Branch, \\ Islamic Azad University, Tehran, Iran
}

Key words: Cut flower, Thyme oil, Nano-malate, Preservative solution

\begin{abstract}
The effect of essential oils and nano-malate in extending the vase-life of Eustoma grandiflorum Mariachii. cv. Blue flower was investigated. The treatment with $3 \mathrm{mM}$ nano-malate increased flower longevity as compared to control. Nano-malate treatment increased chlorophyll, proline and carbohydrate content and membrane stability, while descreasing ACO (ACC-oxidase activity) and MDA (malondialdehyde) content and delay of senescence and peroxidation of lipids. Thyme oil was slightly effective significantly. The application of nano-malate as preservative solutions for $E$. grandiflorum flowers maintained the vase life of flowers for a longer period.
\end{abstract}

Vase life of cut flower is most attractive and economic components of cut flower (Chakrabarty et al. 2009). The main problems of ornamental perishables usually are flowers or leaf senescence (Kazemi and Shokri, 2011). During senescence marked changes occur in the biochemical and biophysical properties of the cell membranes. Ethylene plays a central role in the senescence of many cut flowers (Zagory and Reid 1989). The post harvest quality of many flowers is reduced by ethylene. Ethylene causes premature wilting, color fading, abscission of flower petals and leaf yellowing (Celikel et al. 2002). Essential oils are also used as flavoring agents in food industry. Numerous studies have reported the antimicrobial activity and chemical composition of essential oils (Tepe et al. 2004, Kodali et al. 2005).

Nano-malate is a well-known organic acid that can reduce the number of bacteria in the solution and decrease ACC-oxidase activity which causes delay in the onset of hydrolysis of structural cell components (Kazemi et al. 2010). In this study, effects of thyme oil and nanomalate on the vase life of cut Eustoma grandiflorum Mariachii. cv. blue flowers is reported.

Eustoma grandiflorum Mariachii. cv. Blue were harvested in open stage in the morning by a grower in Tehran, Iran (2013-2014) and chlorophyll content, membrane stability, malondialdehyde content and ACC-oxidase (ACO) activity were measured. Treatments were of thyme oil $(25,50$ and $75 \mathrm{mg} / \mathrm{l})$ and nano-malate $(0.5,1.5$ and $3 \mathrm{mM})$, in a factorial test with complete randomized design with six replications. Distilled water was used for the controls and placed in chambers at $19^{\circ} \mathrm{C}$. The relative humidity was about $70 \%$ while $14 \mathrm{hrs}$ photoperiod was maintained using fluorescent lamps with a light intensity of $15 \mu \mathrm{mol} \mathrm{m} \mathrm{m}^{-1} \mathrm{~s}^{-1}$ at the top of the corolla. The vase life of the inflorescence was considered terminated when $50 \%$ of the open flowers had wilted. Total chlorophyll $(\mathrm{a}+\mathrm{b})$ content was measured by chlorophyll meter (SPAD502 , Minolta Co. Japan) which is presented by SPAD value. Average of 3 measurements from different spots of a single leaf was considered. Anthocyanin leakage was measured based on the method of Poovaiah (1979). ACO was measured based on the method of Moya-Leon and Herrera

*Author for correspondence: <Vabdossi@gmail.com>. 

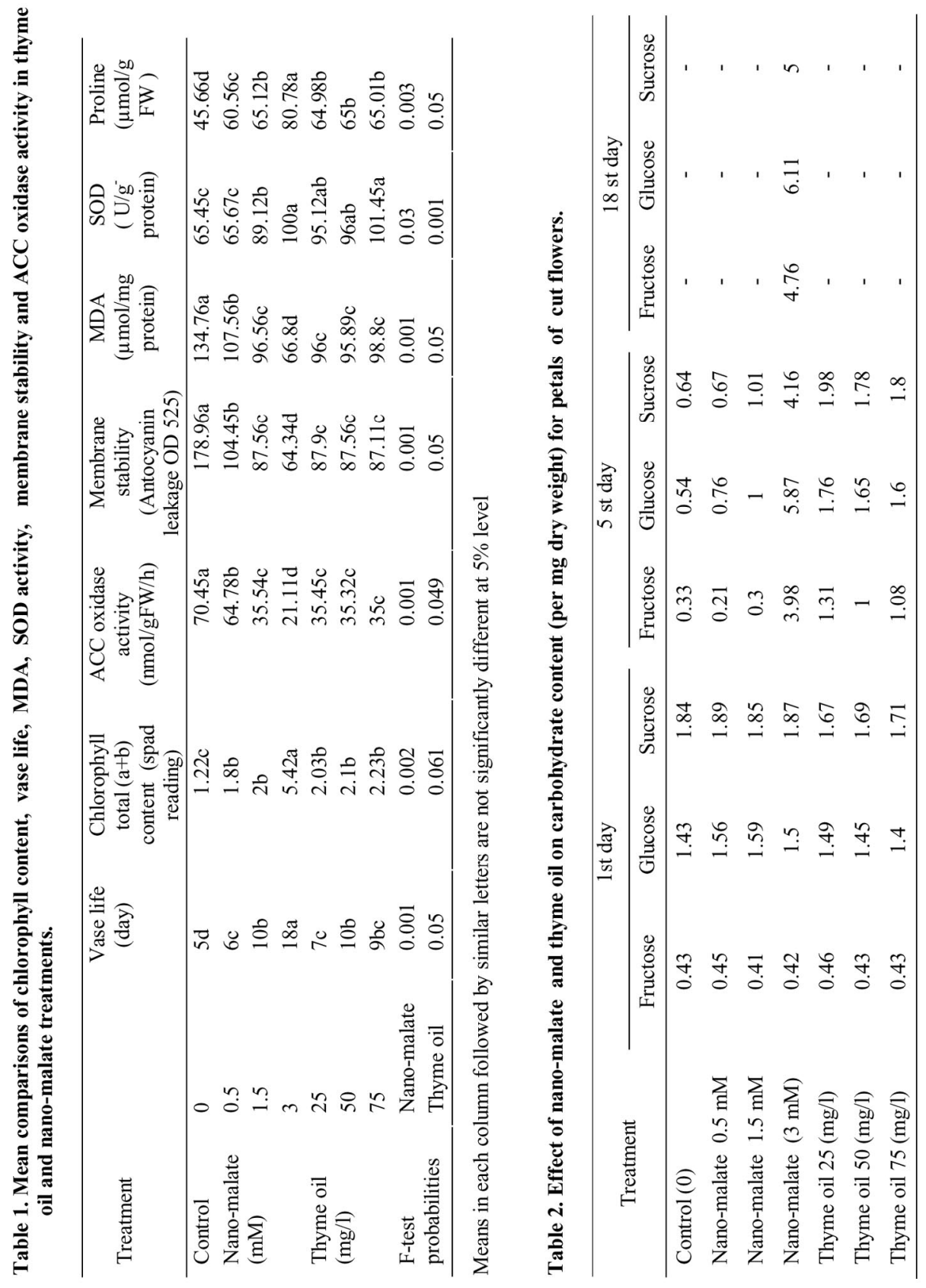
(2004). Oxidative damage to lipids was measured based on the method of Heath and Packer (1968). The activity of superoxide dismutase (SOD) was measured based on the method of Beauchamp and Fridovich (1971). Carbohydrates were measured based on the method of Hassan (2005). Proline were measured based on the method of Bates et al. (1973). Analysis of variance was performed on the data collected using the general linear model (GLM) procedure of the SPSS software (Version 16, IBM Inc.). The mean separation was conducted by Tukey analysis in the same software $(\mathrm{p}=0.05)$.

The nano-malate at concentration $3 \mathrm{mM}$ prolonged the vase life of cut E. grandiflorum flowers, while thyme oil was slightly effective significantly $(\mathrm{p}<0.05)$ as compared to that control (Table 1). The results indicate that $3 \mathrm{mM}$ nano-malate treatment caused a significant increase in chlorophyll content (1.22 to 5.42), membrane stability (178.96 to 64.34), SOD (65.45 to 100), and proline (45.66 to 80.78), while, reduced ACO (70.45 to 21.11) and MDA (134.76 to 66.8). On the other hands, thyme oil has slightly effective significantly $(\mathrm{p}<0.05)$ (Table1). Carbohydrate contents in petals decreased rapidly in present cut flowers in solutions containing control while flowers in the solutions containing $3 \mathrm{mM}$ nano-malate showed the minimum decrease in carbohydrate contents at the end of day $18(\mathrm{p} \leq 0.05)$ (Table 2). In agreement with our result, Kazemi et al. (2010) found that application of MA on cut flower increased vase life and enzyme antioxidant activity. According to the texts, ethylene, reduced vase-life of cut flowers. Ethanol increased vase-life by inhibiting ethylene synthesis and sensitivity to ethylene action. It also inhibited conversion of ACC into ethylene (Wu et al. 1992). Kazemi et al. (2011) reported that treatment with malic acid and salicylic acid significantly extends the vase life with reduced the anthocyanin leakage and ACO activity. Antibacterial agents will keep the water free from bacteria and other microorganisms (Van Doorn et al. 1994). Essential oils have strong antimicrobial properties against some pathogens and bacteria because of high levels of phenolic compounds such as carvacrol, thymol and eugenol. The improved vase life by using Essential oils treated preservative solutions might be due to their role in inhibiting the microbial growth and preventing bacterial plugging. These results are in agreement with those of Saini et al. (1994) and Kazemi et al. (2010) who showed that the vase life of tuberose and carnation cut flowers increased when placed in solutions with different concentrations of essential oils. Reduction in membrane integrity, destruction of enzymatic systems involved in energy production and cellular structure components are the main mechanisms of these compounds in mitigating microbial infection (Sikkema et al. 1995). The application of nano-malate as preservative in solutions E. grandiflorum flowers maintained the vase life of flowers for a longer period.

\section{References}

Çelikel FG, Dodge LL and Reid MS 2002. Efficacy of 1-MCP (1- methylcyclopropene) and promalin for extending the post harvest life of oriental lilies (Lilium $\times$ 'Mona lisa' and 'Stargazer'). Sci. Hort. 93: $149-155$.

Bates LS, Waldren RP and Teare RP 1973. Rapid determination of the free proline of water stress studies. Plant Soil. 39: 205-207.

Beauchamp C and Fridovich 1971. Superoxide dismutase: Improved assay and an assay applicable to acrylamide gels. Annals Biochem. 44: 276-287.

Chakrabarty D, Kumar A and Kumar DS 2009. Oxidative stress and antioxidant activity as the basis of senescence in Hemerocallis (day lily) flowers. J. Hort. Forest. 1(6):113-119.

Hassan F 2005. Improving the postharvest quality of rose cut flowers. Intl. J. Hortic. Sci. 8: 29-32.

Heath RL and Packer L 1968. Photoperoxidation in isolated chloroplast. Kinetics and stochiometry of fatty acid peroxidation. Arch. Biochem. Biophys. 125: 189-198. 
Kazemi M, Aran M and Zamani S 2011. Extending the vase life of Lisianthus (Eustoma grandiflorum Mariachii. cv. blue) with different preservatives. Amer. J. Plant Physiol. 6(3): 167-175.

Kazemi M and Shokri K 2011. Role of salicylic acid in decreases of membrane senescence in cut Lisianthus flowers. World Applied Sci. J. 13(1): 142-146.

Kazemi M, Hadavi E and Hekmati J 2010. The effect of malic acid on the bacterial populations of cut flowers of carnations vase solution. World Appl. Sci J. 10: 737-740

Kordali S, Kotan R, Mavi A and Yildirim A 2005. Determination of the chemical composition and antioxidant activity of the essential of Artemisia dracunculus and of the antifungal and antibacterial activities of Turkish Artemisia absinthium, Artemisia dracunculus, Artemisia santonicum and Artemisia spicigera essential oils. J. Agric. Food. Chem. 53: 9452-9458

Moya-Leon MA and Herrera R 2004. Ripening of mountain papaya (Vasconcellea pubescens) and ethylene dependence of some ripening events. Post harvest Biology and Tech. 34: 211-218.

Poovaiah BW 1979. Increased levels of calcium in nutrient solution improves the post harvest life of potted roses. J. Amer. Soc. Hort. Sci. 104: 164-166.

Saini RS, Yamdaqni R and Sharma SK 1994. Effect of some chemicals on keeping quality and vase-life of tuberose (Polianthes tuberosa L.) cut flowers. Pakistan J. Social Sci. 42: 376-378.

Sikkema J, Bont AM and Poolman B 1995. Mechanism of membrane toxicity of hydrocarbons. Microbiol Rev. 59: 201-222.

Van Doorn WG, Zagory D, Witte YD and Harkema H 1994. Effect of vase-water bacteria on the senescence of cut carnation flowers. Post harvest Biol. Tec. 1: 161-168.

Wu MJ, Zacarias L, Saltveit ME and Reid MS 1992. Alcohols and carnation senescence. Hort Sci. 27: 136-138.

Zagory B and Reid MS 1986. Role of vase solution microorganisms in the life of cut flowers. J. Amr. Soc. Hort. Set. 111(1): 154-I58.

(Manuscript received on 13 July, 2014; revised on 8 September, 2014) 